\title{
Use of sodium metasilicate for management of peach brown $\operatorname{rot}^{1}$
}

\author{
Elizandra Pivotto Pavanello², Auri Brackmann², \\ Ivan Francisco Dressler da Costa ${ }^{2}$, Vanderlei Both ${ }^{2}$, Vagner Ludwig ${ }^{2}$
}

\section{ABSTRACT}

Peach brown rot, caused by the Monilinia fructicola fungus, is the main disease affecting peach crops, and it is mainly controlled via frequent fungicide applications. This study aimed at searching for alternatives to the intensive use of chemicals, evaluating silicon doses to control pre and postharvest peach brown rot and their influence on maturation parameters and fruit quality. Treatments consisted of control (water) and sodium metasilicate doses ( $2 \mathrm{~g} \mathrm{~L}^{-1}, 4 \mathrm{~g} \mathrm{~L}^{-1}, 6 \mathrm{~g} \mathrm{~L}^{-1}, 8 \mathrm{~g} \mathrm{~L}^{-1}$ and $10 \mathrm{~g} \mathrm{~L}^{-1}$ of water). The following assessments were made: spore germination and in vitro mycelial growth, brown rot incidence, soluble solids, titratable acidity, flesh firmness, total polyphenol content and fruit ethylene production and respiration rate. The $2 \mathrm{~g} \mathrm{~L}^{-1}$ dose reduced spore germination by $95 \%$. Doses of $6 \mathrm{~g} \mathrm{~L}^{-1}$ and $8 \mathrm{~g} \mathrm{~L}^{-1}$ satisfactorily reduced the disease incidence in the field, with $77 \%$ and $89.2 \%$ control, respectively. Sodium metasilicate resulted in the maintenance of great fruit firmness, reduced respiration and ethylene production and increased total polyphenol synthesis, but it did not influence the titratable acidity or soluble solids. Applying $6 \mathrm{~g} \mathrm{~L}^{-1}$ may potentially control pre and postharvest peach brown rot, besides increasing the total polyphenol synthesis and maintaining a higher flesh firmness.

KEY-WORDS: Monilinia fructicola; Prunus persica; silicon.

\section{INTRODUCTION}

Brown rot, caused by the Monilinia fructicola (G. Wint.) Honey fungus, is the major cause of pre and postharvest losses in peach crops (Prunus persica). The disease damages flowers and fruits, compromising the orchard, in addition to impacting storage, transport and commercialization (Larena et al. 2005, Villarino et al. 2012). Its chemical control is widely used by fruit growers.

\section{RESUMO}

Uso de metassilicato de sódio no manejo da podridão parda do pessegueiro

A podridão parda do pessegueiro, causada pelo fungo Monilinia fructicola, é a principal doença da cultura, e o seu controle é baseado, principalmente, em frequentes aplicações de fungicidas. Objetivou-se buscar alternativas ao uso intensivo de produtos químicos, avaliando-se doses de silício para o controle pré e pós-colheita da podridão parda e sua influência nos parâmetros de maturação e qualidade dos frutos. Os tratamentos consistiram de testemunha (água) e doses de metassilicato de sódio (2 $\mathrm{g} \mathrm{L}^{-1}$, $4 \mathrm{~g} \mathrm{~L}^{-1}, 6 \mathrm{~g} \mathrm{~L}^{-1}, 8 \mathrm{~g} \mathrm{~L}^{-1}$ e $10 \mathrm{~g} \mathrm{~L}^{-1}$ de água). As avaliações incluíram a germinação de esporos e crescimento micelial in vitro, incidência de podridão parda, sólidos solúveis, acidez titulável, firmeza de polpa, conteúdo de polifenóis totais, produção de etileno e respiração em frutos. A dose de $2 \mathrm{~g} \mathrm{~L}^{-1}$ reduziu em $95 \%$ a germinação dos esporos. Doses de $6 \mathrm{~g} \mathrm{~L}^{-1}$ e $8 \mathrm{~g} \mathrm{~L}^{-1}$ reduziram satisfatoriamente a incidência da doença a campo, com controle de $77 \%$ e $89,2 \%$, respectivamente. O metassilicato de sódio manteve maior firmeza de polpa, reduziu a respiração e a produção de etileno e aumentou a síntese de polifenóis totais, porém, não influenciou na acidez titulável e sólidos solúveis. A aplicação de $6 \mathrm{~g} \mathrm{~L}^{-1}$ tem potencial para o controle pré e pós-colheita da podridão parda do pessegueiro, além de aumentar a síntese de polifenóis totais e manter maior firmeza da polpa.

PALAVRAS-CHAVE: Monilinia fructicola; Prunus persica; silício.

Studies conducted on the efficiency of a number of active ingredients to control brown rot have obtained satisfactory results for difenoconazole, iprodione, tebuconazole, iminoctadine and propiconazole (Moreira \& May-de Mio 2009, Pavanello et al. 2015). However, at least three preharvest fungicide applications are necessary to control it.

Due to the need of control methods that cause less impact on the environment and human health, alternatives are sought to decrease the use of

1. Manuscript received in May/2016 and accepted for publication in Aug./2016 (http://dx.doi.org/10.1590/1983-40632016v4641221).

2. Universidade Federal de Santa Maria, Centro de Ciências Rurais, Santa Maria, RS, Brazil.

E-mails: elizandra_pavanello@yahoo.com.br, auribrackmann@gmail.com,ifdresler@gmail.com, vanderleiboth@yahoo.com.br, vagnerludwig2012@hotmail.com. 
these products, without compromising the control efficiency, thus guaranteeing the productivity and quality of the productive fruit chain.

The application of Si-based products was evaluated by Waldemar Filho et al. (2007), who performed foliar sprays of rock powder or Si-based products to control phytopathogens. Silicon is an important inorganic element that plays a vital role in disease resistance (Bélanger et al. 2003, Rodrigues et al. 2003). This element not only increases plant resistance, but also inhibits fungal growth (Qin \& Tian 2005). One of the hypotheses to explain the ability of silicon to reduce disease severity is that it functions as a physical barrier against fungal appressoria penetration (Chérif et al. 1994, Hayasaka et al. 2008). Silicon has demonstrated potential to control fungal diseases in different fruits, including cherry (Qin \& Tian 2005), cucumber (Chérif et al. 1994), melon and zucchini (Menzies et al. 1992), as well as peach (Biggs et al. 1997, Yang et al. 2010, Nascimento et al. 2014).

For peach crops, many studies have used $\mathrm{Si}$ for postharvest control of the $M$. fructicola fungus (Biggs et al. 1997, Yang et al. 2010, Nascimento et al. 2014), however, there has been no research on its preharvest application. Thus, the present study aimed at determining the most effective dose of sodium metasilicate in the pre and postharvest control of peach brown rot, as well as the influence of this treatment on fruit maturation and quality.

\section{MATERIAL AND METHODS}

To assess the percentage of spore germination and mycelial growth, two isolates of Monilinia fructicola from fruits of different producing regions (Santiago - ISF; Farroupilha - IPRO), in the Rio Grande do Sul State, Brazil, were used. Spore germination (conidia) was assessed using $50 \mu \mathrm{l}$ suspensions containing $10^{5}$ spores $\mathrm{mL}^{-1}$, spread onto Petri dishes containing agar-water medium, plus the concentration $\left(0 \mathrm{~g} \mathrm{~L}^{-1}, 2 \mathrm{~g} \mathrm{~L}^{-1}, 4 \mathrm{~g} \mathrm{~L}^{-1}, 6 \mathrm{~g} \mathrm{~L}^{-1}, 8 \mathrm{~g} \mathrm{~L}^{-1}\right.$ and $10 \mathrm{~g} \mathrm{~L}^{-1}$ ) of sodium metasilicate (Alpha Química Ltda.; 27.5-30 \% of Si and 28.5-30\% of Na), with five Petri dishes per treatment, in a completely randomized design. After $12 \mathrm{~h}$ of incubation in the dark, in a BOD growth chamber $\left(25^{\circ} \mathrm{C}\right), 100$ spores were counted to determine the percentage of germinated spores. Spores in which the germ tube was longer than conidia were considered germinated.
To assess mycelial growth, $6 \mathrm{~mm}$-wide culture disks of $M$. fructicola mycelium removed from cultures with $168 \mathrm{~h}$ of growth were deposited in the center of 10 Petri dishes per treatment, with potato-dextrose-agar medium, containing sodium metasilicate $\left(0 \mathrm{~g} \mathrm{~L}^{-1}, 2 \mathrm{~g} \mathrm{~L}^{-1}, 4 \mathrm{~g} \mathrm{~L}^{-1}, 6 \mathrm{~g} \mathrm{~L}^{-1}, 8 \mathrm{~g} \mathrm{~L}^{-1}\right.$ and $10 \mathrm{~g} \mathrm{~L}^{-1}$ ), and incubated (BOD $25^{\circ} \mathrm{C}$ ) for a photoperiod of $12 \mathrm{~h}$. After 7 days, colony growth was measured with a vernier caliper.

The study was conducted in a commercial

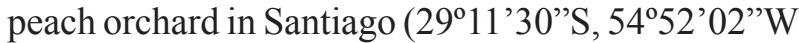
and altitude of $409 \mathrm{~m}$ ). The 'Pepita' cultivar, with early maturation and susceptible to brown rot, was used. The plants ( 8 years old) were grown under a Y-trellis system, spaced $1.5 \mathrm{~m}$ between plants and $5 \mathrm{~m}$ between lines. Previous practices involved fertilizing and phytosanitary control, in addition to fruit pruning and thinning.

Phytosanitary management initiated with the elimination of mummified fruits in the resting period, followed by chemical treatments after flowering. The

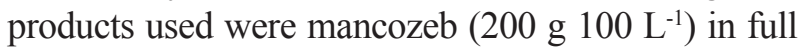

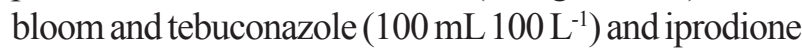
$\left(150 \mathrm{~mL} 100 \mathrm{~L}^{-1}\right)$ from the petal fall stage until 21 days before harvest. Applications were made with a 13 L backpack sprayer (Jacto, cone nozzle), following recommended doses for each active ingredient and adapting them to a spray volume of $1,000 \mathrm{~L} \mathrm{ha}^{-1}$.

Similarly, after this period, sprayings were carried out using a solution of sodium metasilicate $\left[\mathrm{Na}_{2} \mathrm{O}\left(\mathrm{SiO}_{2}\right)\right]$, with $\mathrm{pH} 10.5$, at $14(10 / 08 / 2013)$ and $7(10 / 15 / 2013)$ days before harvest, applying the treatments control (water application) and sodium metasilicate doses $\left(2 \mathrm{~g} \mathrm{~L}^{-1}, 4 \mathrm{~g} \mathrm{~L}^{-1}, 6 \mathrm{~g} \mathrm{~L}^{-1}, 8 \mathrm{~g} \mathrm{~L}^{-1}\right.$ and $10 \mathrm{~g} \mathrm{~L}^{-1}$ of water). Meteorological data, during the growing cycle and at the treatment application, are shown in Figure 1. The sodium metasilicate experiment followed a complete randomized blocks design, with four repetitions and six treatments. Each experimental unit was composed of four plants, two of which corresponded to the border, with the central plants used for testing.

To determine the incidence of the disease in the field, the number of fruits with lesions was assessed, in relation to the total number analyzed between the first and third harvest, totaling an evaluation period of 10 days. The results were expressed in percentage of fruits with brown rot. After the harvest, 25 fruits from each repetition and at the same maturation stage were randomly sampled and taken to the laboratory, where 

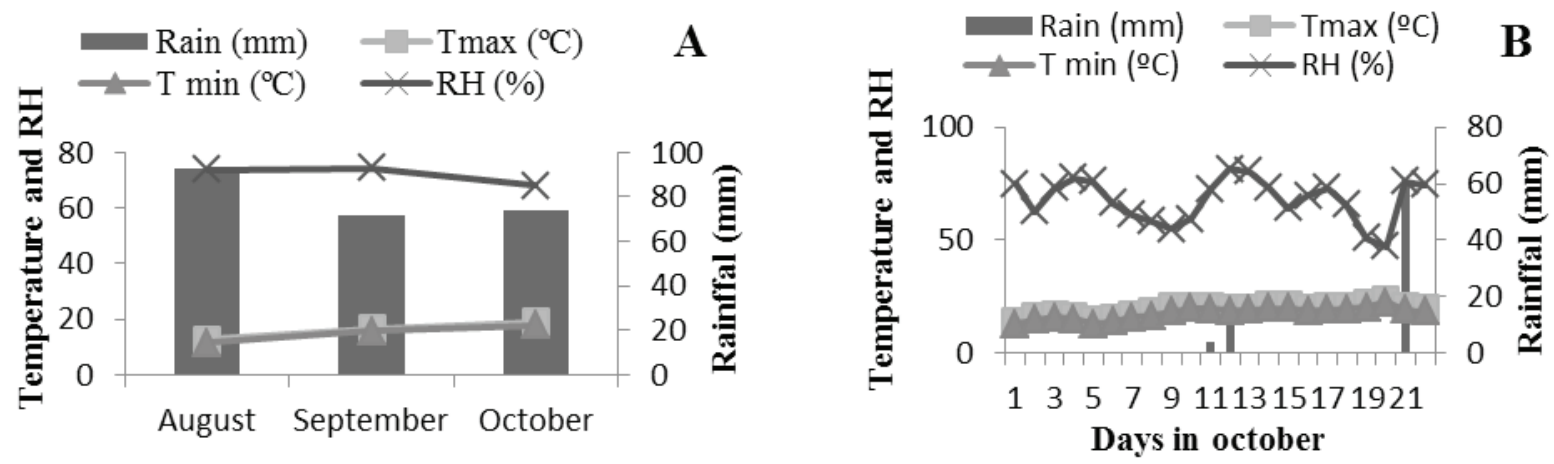

Figure 1. Rainfall, relative humidity $(\mathrm{RH})$ and temperature $(\mathrm{T})$ observed at the Santiago meteorological station, during the productive cycle of the peaches cv. 'Pepita', in 2013.

they were kept in a $400 \mathrm{~L}$ chamber, at a temperature of $20^{\circ} \mathrm{C}$, for four days. The postharvest incidence of the disease was assessed by counting the fruits that exhibited lesions characteristic of infection by $M$. fructicola, with results expressed in percentage of symptomatic fruits.

The fruits were assessed for maturation and quality, using 15 fruits per repetition, and the following parameters were analyzed:

a) Soluble solids (SS) content: obtained by refractometry of the juice extracted from each repetition, with results expressed in ${ }^{\circ}$ Brix;

b) Titratable acidity (TA): determined by titration, with $0.1 \mathrm{~N} \mathrm{NaOH}$ of a solution containing $10 \mathrm{~mL}$ of juice diluted in $100 \mathrm{~mL}$ of distilled water, until reaching $\mathrm{pH} 8.1$, and expressed in meq $100 \mathrm{~mL}^{-1}$;

c) Total polyphenols: determined by the colorimetric method (Singleton \& Rossi Junior 1965). A test tube was filled with $200 \mu \mathrm{L}$ of diluted sample (1:10), in an ethanol/acid hydrochloric acid/ water solution, at a proportion of 70/1/30 (V/V/V), and $1,000 \mu \mathrm{L}$ of Folin-Ciocalteu reagent, diluted (1:10) in distilled and deionized water. After 3-8 min, $800 \mu \mathrm{L}$ of $7.5 \% \mathrm{Na}_{2} \mathrm{CO}_{3}$ was added. After $2 \mathrm{~h}$ in the dark, absorbance was read at $765 \mathrm{~nm}$, in a FEMTO 600S (single-beam) spectrophotometer. A solution of gallic acid, at the concentrations of $15 \mathrm{mg} \mathrm{L}^{-1}$, $30 \mathrm{mg} \mathrm{L}^{-1}, 45 \mathrm{mg} \mathrm{L}^{-1}, 60 \mathrm{mg} \mathrm{L}^{-1}, 75 \mathrm{mg} \mathrm{L}^{-1}$ and $90 \mathrm{mg} \mathrm{L}^{-1}$, was used as standard for the calibration curve. The total polyphenol concentration was expressed in $\mathrm{mg} 100 \mathrm{~g}^{-1}$;

d) Flesh firmness: assessed on two opposite sides, in the equatorial region of the fruits, where part of the epidermis was previously removed. To that end, a manual penetrometer, with a $7.9 \mathrm{~mm}$ probe, was used, and values were expressed in Newtons $(\mathrm{N})$; e) Ethylene production: determined with the use of approximately 1,200 $\mathrm{g}$ of fruits, placed in $5,000 \mathrm{~mL}$ glass containers, and closed for about $1 \mathrm{~h}$. To analyze the ethylene production, two $1 \mathrm{~mL}$ samples of gas from each container were injected into a Varian ${ }^{\circledR}$ Star 3400 CX gas chromatograph, equipped with a flame ionization detector (FID) and Porapak N80/100 column. The temperatures of the column, injector and detector were respectively $90{ }^{\circ} \mathrm{C}, 140{ }^{\circ} \mathrm{C}$ and $200{ }^{\circ} \mathrm{C}$. Ethylene synthesis was assessed at harvest, two and four days after fruits were exposed to $20^{\circ} \mathrm{C}$, calculated and expressed as $\mu \mathrm{L} \mathrm{C}_{2} \mathrm{H}_{4} \mathrm{~kg}^{-1} \mathrm{~h}^{-1}$, as a function of ethylene concentration, fruit mass, volume of free space in the container and length of time it was closed;

f) Respiration rate: determined at harvest, two and four days after fruits were exposed to $20^{\circ} \mathrm{C}$, by quantifying the $\mathrm{CO}_{2}$ production. The air from the same container used for ethylene determination was circulated through a Schele electronic $\mathrm{CO}_{2}$ analyzer. Respiration in $\mathrm{mL} \mathrm{CO}_{2} \mathrm{~kg}^{-1} \mathrm{~h}^{-1}$ was calculated from the $\mathrm{CO}_{2}$ concentration, volume of free container space, length of time it was closed and fruit weight.

The data obtained were submitted to analysis of variance and polynomial regression at $5 \%$, using the Sisvar 5.3 software.

\section{RESULTS AND DISCUSSION}

The doses of sodium metasilicate resulted in exponential and linear behavior in spore germination and mycelial growth, respectively (Figures 2A and 2B).

Spore germination was reduced by approximately $95 \%$, in relation to the controls, with a dose of $2 \mathrm{~g} \mathrm{~L}^{-1}$, and totally inhibited with 
$6 \mathrm{~g} \mathrm{~L}^{-1}$ or more of sodium metasilicate, irrespective of the isolate assessed. Similar results were obtained with calcium silicate (Biggs et al. 1997, Yang et al. 2010) and sodium metasilicate (Quin \& Tian 2005, Nascimento et al. 2014), which significantly inhibited spore germination at a dose of $2 \mathrm{~g} \mathrm{~L}^{-1}$ or higher.

In addition to Monilinia fructicola, siliconbased products have exhibited satisfactory results in reducing the spore germination of Trichothecium roseum (Guo et al. 2007, Li et al. 2012), Fusarium sulphureum (Li et al. 2009), Penicillium digitatum (Liu et al. 2010) and Penicillium expansum (Quin \& Tian 2005).

The effect of silicon may be attributed to its osmotic action, due to the alkaline nature of the products applied (Liang et al. 2005, Guével et al. 2007, Carré-Missio et al. 2012), as observed with the $\mathrm{pH}$ of 10.5 , in the solution of sodium metasilicate used in the present study.
Linear behavior was found for mycelial growth, with less colony growth at a dose of $10 \mathrm{~g} \mathrm{~L}^{-1}$ of sodium metasilicate (Figure 2B). However, no complete growth inhibition was observed, confirming the results obtained by Yang et al. (2010), with a dose of $2 \mathrm{~g} \mathrm{~L}^{-1}$. According to Kaiser et al. (2005), silicon affects the mycelial growth of several phytopathogenic fungi. Thus, at least in the in vitro condition, sodium metasilicate seems to have a more important effect on fungal spore germination, affecting the establishment of the disease more than its mycelial growth.

The incidence of brown rot in the field was lower with the application of sodium metasilicate from the first to the third harvest (Figure 3A). Sodium metasilicate was applied twice, at 14 and 7 days before harvest, according to the treatment concentration. For the first harvest, the dose with the best fit was $7 \mathrm{~g} \mathrm{~L}^{-1}$, while a dose of $7.5 \mathrm{~g} \mathrm{~L}^{-1}$ had
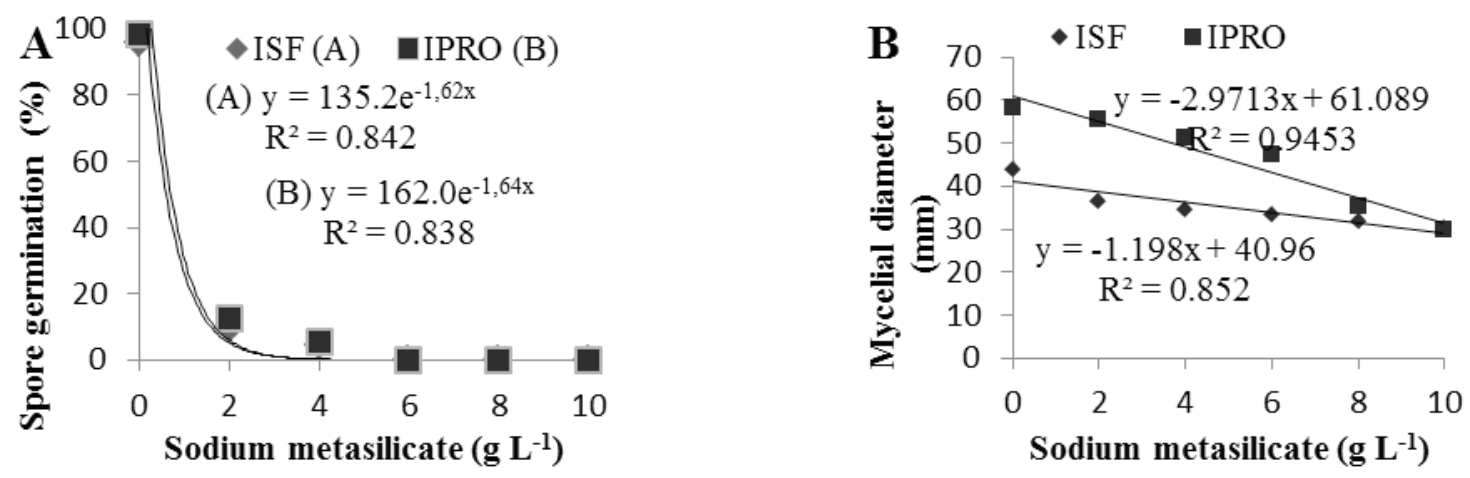

Figure 2. Effect of in vitro sodium metasilicate doses on spore germination (A) and mycelial diameter (B), in two Monilinia fructicola isolates. * $5 \%$ significance level $(\mathrm{p}<0.05)$ for the F-test. ** ISF and IPRO: nomenclature of isolates from two producing regions in the Rio Grande do Sul State.
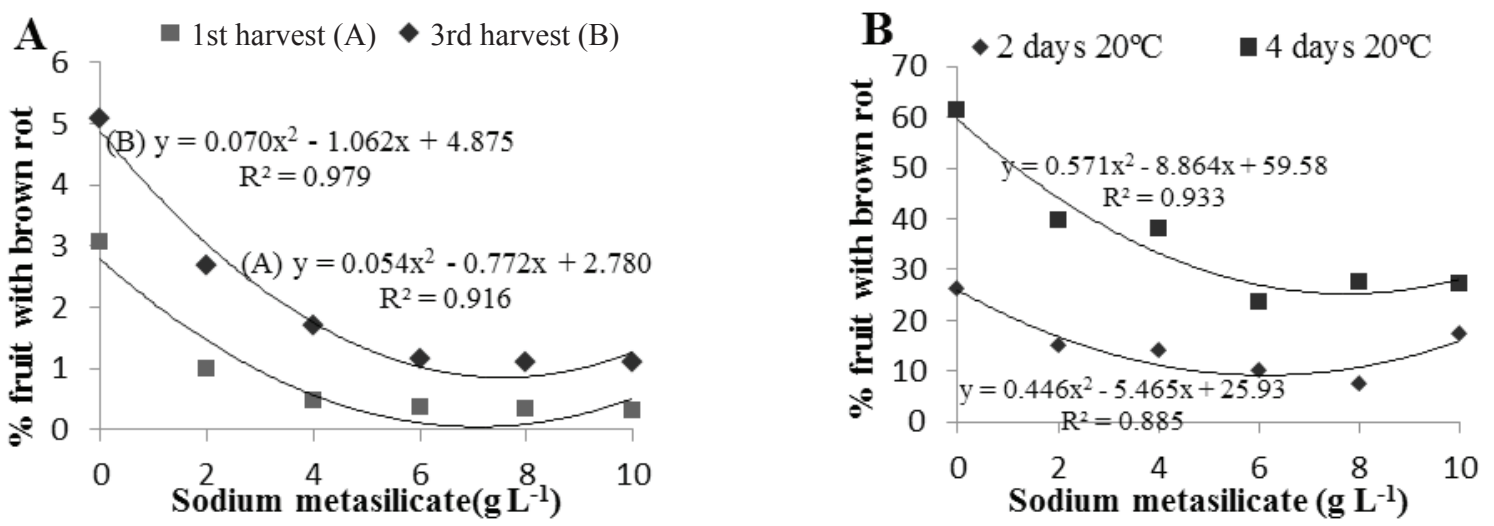

Figure 3. Brown rot incidence in peaches cv. 'Pepita' in the field, after the application of sodium metasilicate at 14 and 7 days preharvest $(\mathrm{C})$ and during two and four days of fruit exposure to a temperature of $20^{\circ} \mathrm{C}$ at postharvest (D). $* 5 \%$ significance level $(\mathrm{p}<0.05)$ for the F-test. 
the lowest incidence after the third harvest. Doses of $6 \mathrm{~g} \mathrm{~L}^{-1}$ and $8 \mathrm{~g} \mathrm{~L}^{-1}$ satisfactorily reduced the incidence of brown rot in the field, with control of $77 \%$ and $89.2 \%$, respectively, without a phytotoxic effect on plants. Some plants submitted to doses higher than $8 \mathrm{~g} \mathrm{~L}^{-1}$ showed senescent stains, primarily at the leaves edges. Furthermore, in preliminary tests, this damage was observed only with the application of doses above $10 \mathrm{~g} \mathrm{~L}^{-1}$. Thus, due to the discrepant results, it is preferable to use smaller doses, such as $6 \mathrm{~g} \mathrm{~L}^{-1}$ of sodium metasilicate, which exhibits good control of the disease, with less risk of phytotoxic effects.

In postharvest, the results fit a second degree polynomial equation, in which doses of $6 \mathrm{~g} \mathrm{~L}^{-1}$ and $8 \mathrm{~g} \mathrm{~L}^{-1}$ displayed the lowest incidence of brown rot after two and four days of fruit exposure to $20{ }^{\circ} \mathrm{C}$, respectively (Figure 3B). Although all the metasilicate doses reduced the incidence, if compared to the controls, none of them controlled the incidence by more than $62 \%$. The preharvest use of sodium metasilicate exhibited good results in terms of disease management in the field, but the effect was smaller during the fruits shelf life, albeit greater than that for the controls.
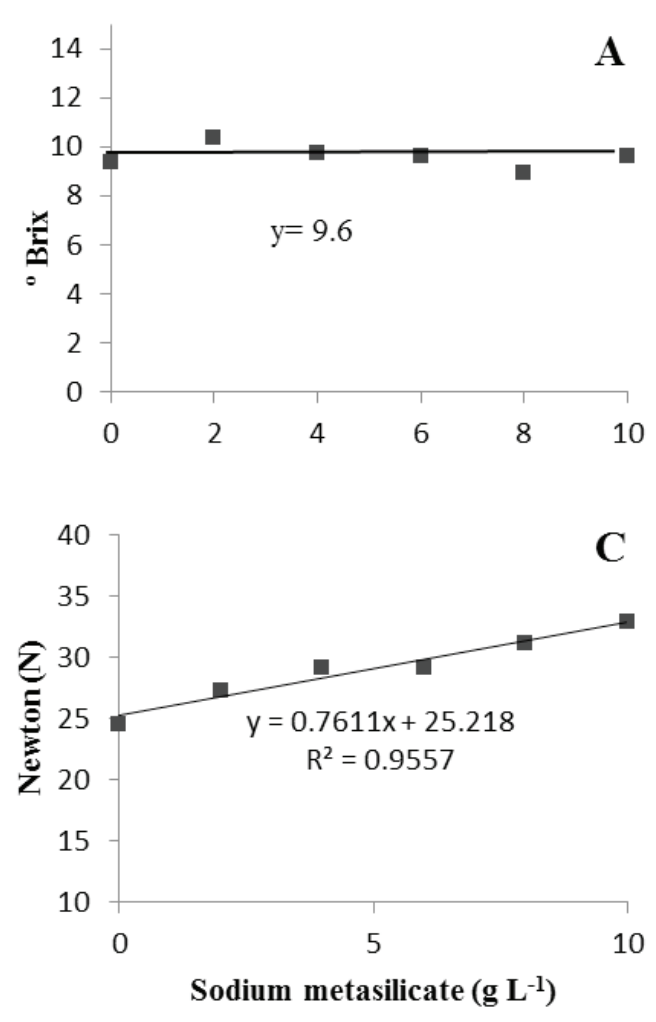

The use of silicon in the postharvest of peaches has demonstrated satisfactory results with the application of sodium metasilicate (Quin \& Tian 2005, Nascimento et al. 2014) and sodium silicate in peaches and apples (Biggs et al. 1997, Yang et al. 2010). The results of the present study, considered pioneering in the foliar application of $\mathrm{Si}$ to peach trees, suggest that sodium metasilicate has the potential to control M. fructicola, when applied at 14 to 7 days preharvest. The use of Si in the field to control diseases has been widely studied in recent years, for various species (Moraes et al. 2006, Buck et al. 2008, Duarte et al. 2008), as well as its effect on inducing resistance, such as the formation of physical barriers, polyphenol synthesis (Chérif et al. 1994, Gomes et al. 2005, Hayasaka et al. 2008) and fungal inhibition (Tian et al. 2005, Yang et al. 2010). Spore germination was totally inhibited with the use of $6 \mathrm{~g} \mathrm{~L}^{-1}$ of sodium metasilicate (Figure 2A)

With respect to the assessment of fruit quality, no effect of sodium metasilicate application was observed on soluble solids and titratable acidity (Figures 4A and 4B). For flesh firmness, the doses exhibited a linear effect, with higher doses
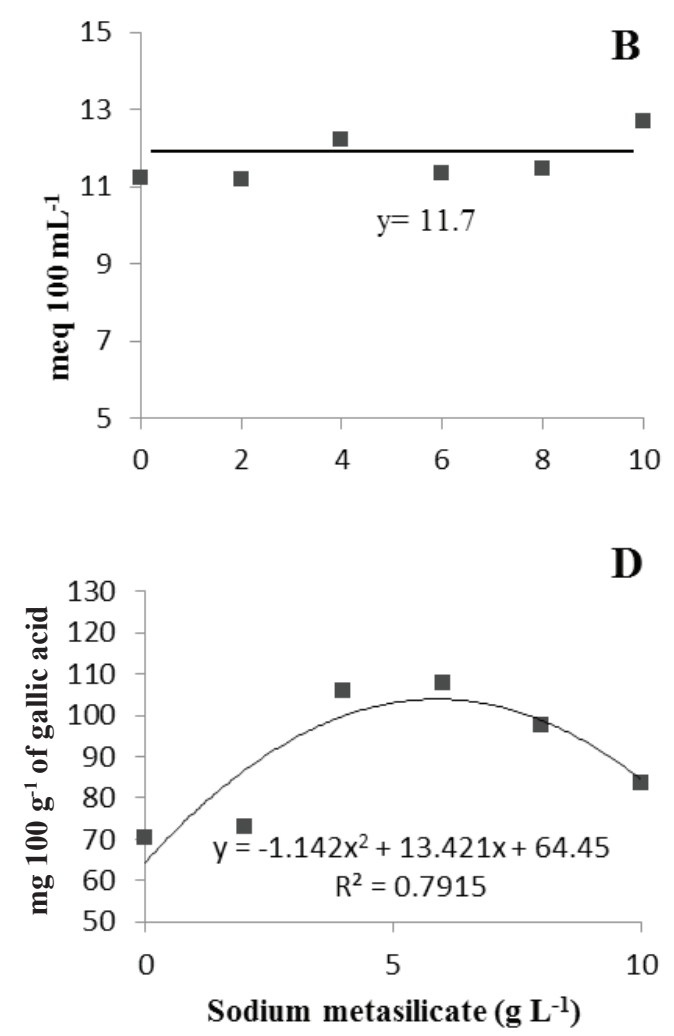

Figure 4. Total soluble solids (A), titratable acidity (B), flesh firmness (C) and total polyphenols (D), after harvesting peaches treated with sodium metasilicate at 14 and 7 days preharvest. * $5 \%$ significance level $(\mathrm{p}<0.05)$ for the F-test. 
maintaining greater firmness (Figure 4C). Total polyphenol content was also significantly influenced by doses of sodium metasilicate, with the effect fitting to a second degree polynomial curve, with maximum efficacy at a dose of $6 \mathrm{~g} \mathrm{~L}^{-1}$ (Figure 4D). These results are in line with the most effective doses to control brown rot, suggesting that sodium metasilicate may act as an inducer of resistance in peaches, increasing flesh firmness and total polyphenol content.

Resistance to brown rot in peach farming is correlated to preformed structural plant defense mechanisms, such as cuticle thickness, epidermal cell compaction and phenolic compound production (Ghanmi et al. 2004, Lee \& Bostock 2007). Michailidis \& Johnson (1992) reported that, after spores germinated, resistance to infection by Monilinia fructicola was associated with cuticle and cell wall thickness, in which the quiescent period of the fungus was prolonged according to the increase in cuticle and cell wall thickness of peaches. In addition to physical defenses, in cucumber, Si activates the chemical defenses of plants, promoting an increase in the phenolic compound level (Fawe et al. 1998), as well as the chitinase and $\beta-1,3$-glucanase activity (Chérif et al. 1994).

Ethylene production showed a linear effect, in which the increase in metasilicate doses resulted in reduced ethylene production for all assessment dates (Figures 5B, 5D and 5F). The fruits respiratory rate showed no difference between sodium metasilicate
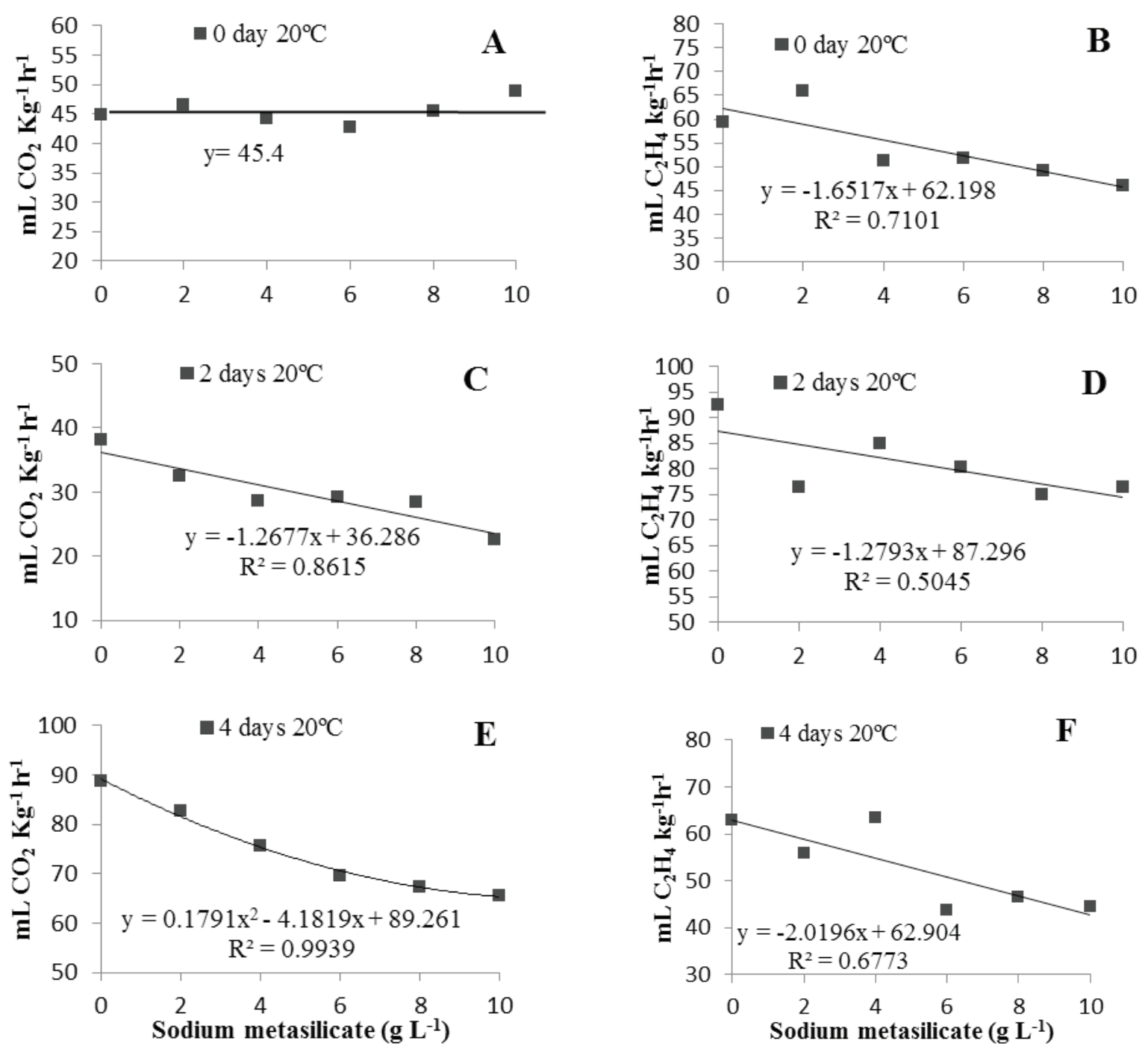

Figure 5. Respiration rate (A, C, E) and ethylene production (B, D, F), during four days of fruit exposure to $20^{\circ} \mathrm{C}$, in peaches treated with sodium metasilicate, at 14 and 7 days preharvest. * $5 \%$ significance level $(\mathrm{p}<0.05)$ for the F-test. 

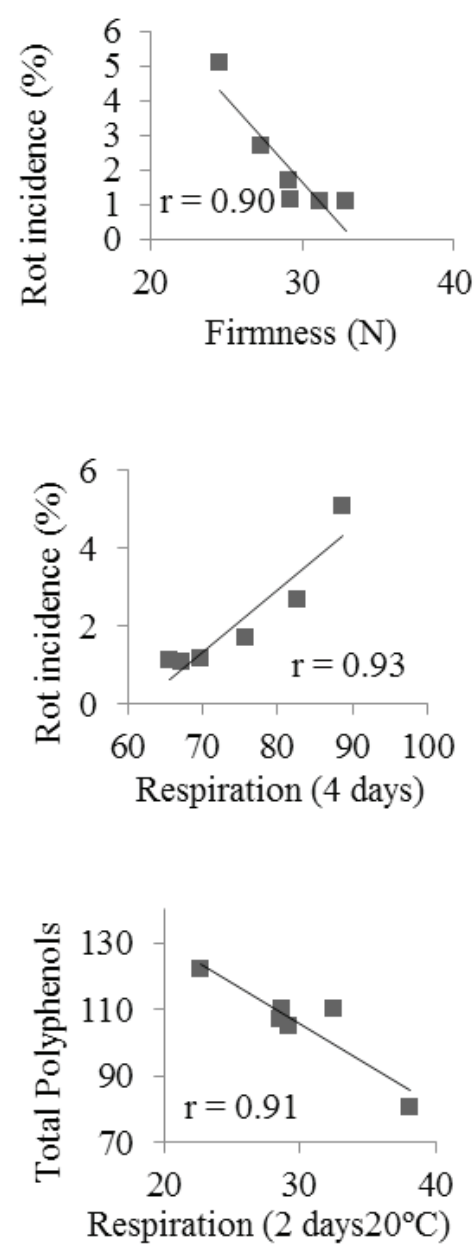
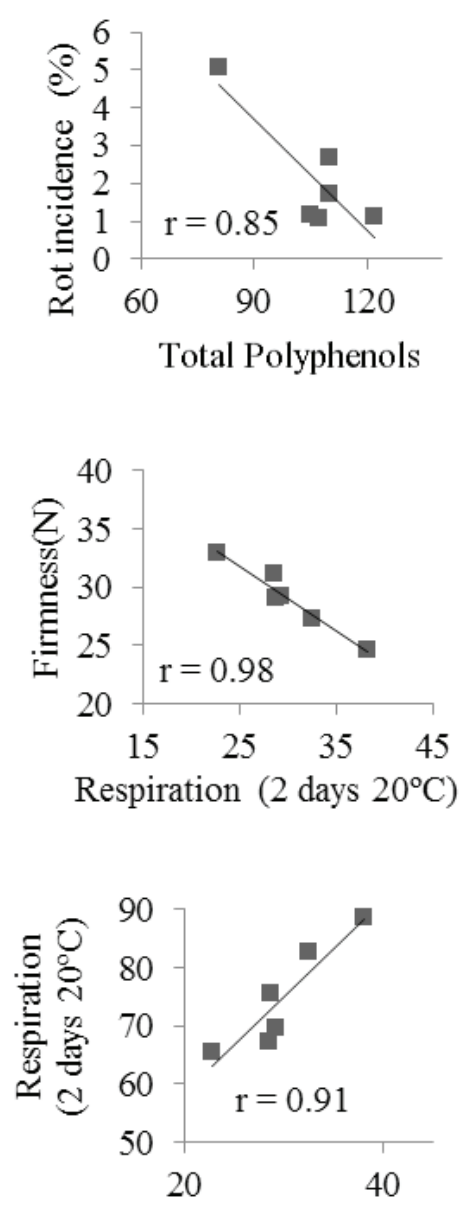

Respiration (4 days $20^{\circ} \mathrm{C}$ )

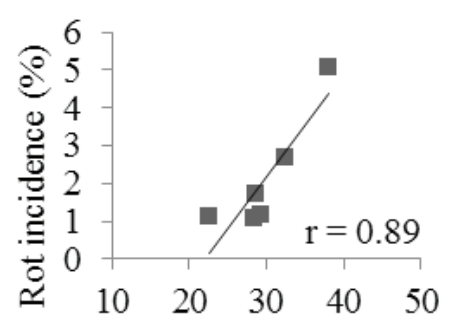

Respiration $\left(2\right.$ days $\left.20^{\circ} \mathrm{C}\right)$
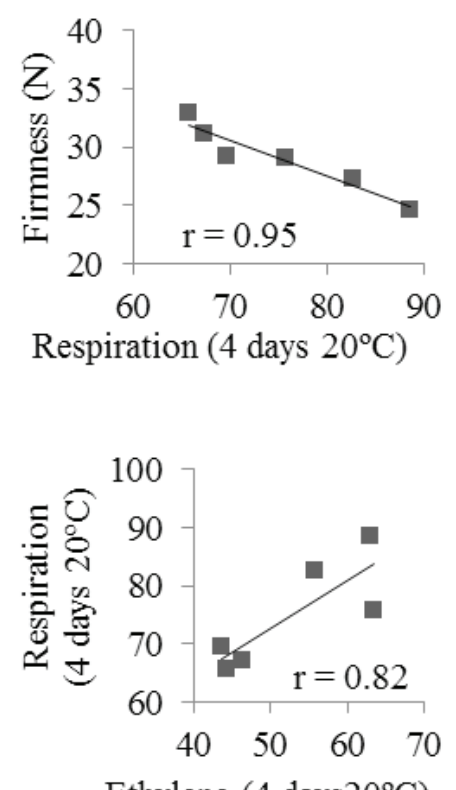

Ethylene (4 days $\left.20^{\circ} \mathrm{C}\right)$

Figure 6. Pearson's correlation between variables in peaches cv. 'Pepita' treated with sodium metasilicate at preharvest.

doses at harvest. However, after two and four days of exposure to $20^{\circ} \mathrm{C}$, respiration decreased with the increase in doses (Figures 5A, 5C and 5E). These results indicate that metasilicate likely reduced fruit maturation, which may have maintained flesh firmness.

The positive results in reducing the incidence of brown rot using sodium metasilicate were likely due to the effect of the product as a fungicide, primarily the osmotic action caused by the high $\mathrm{pH}$ of the solution. However, the incidence of brown rot showed a negative correlation with flesh firmness and total polyphenol content, and a positive relationship with respiration rate at two and four days (Figure 6), probably indicating the effect of sodium metasilicate on the resistance of fruits to infection by the Monilinia fructicola fungus.

A negative correlation was observed between flesh firmness and respiration at two and four days. This result indicates the potential of sodium metasilicate as an inducer of plant resistance to the pathogen, reinforcing the need for new studies primarily exploring its effect on the formation of physical barriers against infection and production of compounds related to pathogenesis.

The results showed the potential of sodium metasilicate to control peach brown rot, highlighting the need for studies using it at preharvest, alone and in conjunction with fungicides, in order to reduce the high number of fungicide applications.

\section{CONCLUSIONS}

1. Doses of sodium metasilicate greater than or equal to $6 \mathrm{~g} \mathrm{~L}^{-1}$ completely inhibit the in vitro germination of Monilinia fructicola spores;

2. The application of $6 \mathrm{~g} \mathrm{~L}^{-1}$ of sodium metasilicate, at 14 and 7 days before harvest, reduces the pre 
and postharvest incidence of peach brown rot, increases total polyphenol synthesis and maintains flesh firmness in peaches cv. 'Pepita';

3. Sodium metasilicate applied at preharvest maintains greater flesh firmness and reduces respiration and ethylene production of fruits, but it does not affect titratable acidity or soluble solids;

4. Sodium metasilicate is an alternative to control preharvest brown rot, because it is less toxic and protects fruits during the harvest period.

\section{REFERENCES}

BÉLANGER, R. R. et al. Cytological evidence of an active role of silicon in wheat resistance to powdery mildew (Blumeria graminis f. sp. tritici). Phytopathology, v. 93, n. 4, p. 402-412, 2003.

BIGGS, A. R. et al. Effects of calcium salts on growth, polygalacturonase activity, and infection of peach fruit by Monilinia fructicola. Plant Disease, v. 81, n. 4, p. 399403, 1997.

BUCK, G. B. et al. Potassium silicate as foliar spray and rice blast control. Journal of Plant Nutrition, v. 31, n. 2 , p. 231-237, 2008.

CARRÉ-MISSIO, V. et al. Componentes epidemiológicos da ferrugem do cafeeiro afetados pela aplicação foliar de silicato de potássio. Tropical Plant Pathology, v. 37, n. 1, p. 50-56, 2012.

CHÉRIF, M.; ASSELIN, A.; BELANGER, R. R. Defense responses induced by soluble silicon in cucumber roots infected by Pythium spp. Phytopathology, v. 84, n. 2, p. 236-242, 1994.

DUARTE, H. da S. S. et al. Efeito do silicato de potássio isoladamente ou em mistura com fungicida no controle da requeima da batateira. Summa Phytopathologica, v. 34, n. 1, p. 68-70, 2008.

FAWE, A. et al. Silicon-mediated accumulation of flavonoid phytoalexins in cucumber. Phytopathology, v. 88, n. 5 , p. $396-401,1998$.

GHANMI, D. et al. Powdery mildew of Arabidopsis thaliana: a pathosystem for exploring the role of silicon in plant-microbe interactions. Physiological and Molecular Plant Pathology, v. 64, n. 4, p. 189-199, 2004.

GOMES, F. B. et al. Resistance induction in wheat plants by silicon and aphids. Scientia Agricola, v. 62, n. 6, p. 547$551,2005$.

GUÉVEL, M. H.; MENZIES, J. G.; BÉLANGER, R. R. Effect of root and foliar applications of soluble silicon on powdery mildew control and growth of wheat plants.
European Journal of Plant Pathology, v. 119, n. 1, p. 429436, 2007.

GUO, Y. et al. Use of silicon oxide and sodium silicate for controlling Trichothecium roseum postharvest rot in Chinese cantaloupe (Cucumis melo L.). International Journal of Food Science and Technology, v. 42, n. 8, p. 1012-1018, 2007.

KAISER, C. et al. In-vitro inhibition of mycelial growth of several phytopathogenic fungi, including Phytophthora cinnamomi by soluble silicon. South African Avocado Growers'Association Yearbook, v. 28, n. 1, p. 70-74, 2005.

HAYASAKA, T.; FUJII, H.; ISHIGURO, K. The role of silicon in preventing appressorial penetration by the rice blast fungus. Phytopathology, v. 98, n. 9, p. 1038-1044, 2008.

LARENA, I. et al. Biological control of postharvest brown rot (Monilinia spp.) of peaches by field applications of Epicoccum nigrum. Biological Control, v. 32, n. 2, p. 305310, 2005.

LEE, M. H.; BOSTOCK, R. M. Fruit exocarp phenols in relation to quiescence and development of Monilinia fructicola infections in Prunus spp.: a role for cellular redox. Phytopathology, v. 97, n. 3, p. 269-277, 2007.

LI, W. et al. Effects of postharvest sodium silicate treatment on pink rot disease and oxidative stress-antioxidative system in muskmelon fruit. European Food Research and Technology, v. 234, n. 1, p. 137-145, 2012.

LI, Y. C. et al. Antifungal activity of sodium silicate on Fusarium sulphureum and its effect on dry rot of potato tubers. Journal of Food Science, v. 74, n. 5, p. 213-218, 2009.

LIANG, Y. C. et al. Effects of foliar and root applied silicon on the enhancement of induced resistance to powdery mildew in Cucumis sativus. Plant Pathology, v. 54, n. 1, p. 678-685, 2005.

LIU, J. et al. Plasma membrane damage contributes to antifungal activity of silicon against Penicillium digitatum. Current Microbiology, v. 61, n. 4, p. 274-279, 2010.

MENZIES, J. G. et al. Foliar application of potassium silicate reduces severity of powdery mildew on cucumber, muskmelon and zucchini squash. Journal of the American Society for Horticultural Science, v. 117, n. 6, p. 902-905, 1992.

MICHAILIDIS, T. J.; JOHNSON, R. S. Effect of nitrogen fertilization on brown rot (Monilinia fructicola) susceptibility in nectarines. Phytopathology, v. 10, n. 1, p. 1064, 1992.

MORAES, S. R. G. et al. Efeito de fontes de silício na incidência e na severidade da antracnose do feijoeiro. Fitopatologia Brasileira, v. 31, n. 1, p. 69-75, 2006. 
MOREIRA, L. M.; MAY-DE MIO, L. M. Controle da podridão parda do pessegueiro com fungicidas e fosfitos avaliados em pré e pós-colheita. Ciência e Agrotecnologia, v. 33, n. 2, p. 405-411, 2009.

NASCIMENTO, F. V. et al. UV-C effect and alternative treatments for postharvest control of brown rot in peaches. Acta Horiculturae, v. 1053, n. 2, p. 265-272, 2014.

PAVANELLO, E. P. et al. Eficiência de fungicidas no controle da podridão parda do pessegueiro e sua relação com parâmetros fisiológicos dos frutos. Semina: Ciências Agrárias, v. 36, n. 1, p. 67-76, 2015.

QIN, G. Z.; TIAN, S. P. Enhancement of biocontrol activity of Cryptococcus laurentii by silicon and the possible mechanisms involved. Phytopathology, v. 95, n. 1, p. 69-75, 2005.

RODRIGUES, F. A. et al. Effect of rice growth stages and silicon on sheath blight development. Phytopathology, v. 93 , n. 3, p. 256-261, 2003.

SINGLETON, V. L.; ROSSI JUNIOR, J. A. Colorimetry of total phenolics with phosphomolybdic-phosphotungstic acid reagents. American Journal of Enology and Viticulture, v. 16, n. 3, p. 144-158, 1965.

TIAN, S. P. et al. Synergistic effects of combining biocontrol agents with silicon against postharvest diseases of jujube fruit. Journal of Food Protection, v. 68, n. 3, p. 544-550, 2005.

VILLARINO, M. et al. Secondary inoculum dynamics of Monilinia spp. and relationship to the incidence of postharvest brown rot in peaches and the weather conditions during the growing season. European Journal of Plant Pathology, v. 133, n. 3, p. 585-598, 2012.

WALDEMAR FILHO, P. de C. et al. Algumas sugestões para a expansão da agropecuária orgânica no Estado de São Paulo. Informações Econômicas, v. 37, n. 6, p. 5061, 2007.

YANG, L. et al. Synergistic effect of oligochitosan and silicon on inhibition of Monilinia fructicola infections. Journal of Science Food Agriculture, v. 90, n. 4, p. 630634, 2010. 